\title{
Targeting protein dynamics in drug design
}

\author{
Rebecca C Wade ${ }^{1,2}$ \\ From 8th German Conference on Chemoinformatics: 26 CIC-Workshop \\ Goslar, Germany. 11-13 November 2012
}

The dynamic nature of protein structures provides challenges and opportunities for ligand design. I will first discuss some of the different ways in which protein dynamics can be targeted, giving examples from our experience in the design of inhibitors of thymidylate synthase [1-3]. I will then describe the development of a computational toolbox (TRAPP: TRAnsient Pockets in Proteins) to identify and visualize transient pockets in proteins that may be exploited in ligand design.

\footnotetext{
Author details

${ }^{1}$ Molecular and Cellular Modeling Group, Heidelberg Institute for Theoretical Studies (HITS), Germany. ${ }^{2}$ Center for Molecular Biology (ZMBH), Heidelberg

University, Heidelberg, Germany.
}

Published: 22 March 2013

\section{References}

1. Ferrari S, Costi MP, Wade RC: Inhibitor specificity via protein dynamics: Insights from design of antibacterial agents targeted against thymidylate synthase. Chem \& Biol 2003, 10:1183-1193.

2. Salo-Ahen OMH, Wade RC: The Active-Inactive Transition of Human Thymidylate Synthase: Targeted Molecular Dynamics Simulations. Proteins: Struct, Funct, Bioinf 2011, 79:2886-2899.

3. Cardinale D, Guaitolia G, Tondi D, Luciani R, Henrich S, Salo-Ahen OMH, Ferrari S, Marverti G, Guerrieri D, Ligabue A, Frassineti C, Pozzi C, Mangani S, Fessas D, Guerrini R, Ponterini G, Wade R, Costi MP: Protein-protein interfacebinding peptides inhibit the cancer therapy target human thymidylate synthase. Proc Natl Acad Sci USA 2011, 108:13889-13890, E542-E549.

Correspondence: Rebecca.wade@h-its.org

'Molecular and Cellular Modeling Group, Heidelberg Institute for Theoretical Studies (HITS), Germany

Full list of author information is available at the end of the article

\footnotetext{
Publish with ChemistryCentral and every scientist can read your work free of charge

"Open access provides opportunities to our colleagues in other parts of the globe, by allowing anyone to view the content free of charge."

W. Jeffery Hurst, The Hershey Company.

- available free of charge to the entire scientific community

- peer reviewed and published immediately upon acceptance

- cited in PubMed and archived on PubMed Central

- yours - you keep the copyright

Submit your manuscript here:

http://www.chemistrycentral.com/manuscript/

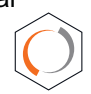

Chemistry Central
}

() Chemistry Central

(c) 2013 Wade; licensee BioMed Central Ltd. This is an Open Access article distributed under the terms of the Creative Commons Attribution License (http://creativecommons.org/licenses/by/2.0), which permits unrestricted use, distribution, and reproduction in any medium, provided the original work is properly cited. 